\title{
Investigation of the Biological Treatability of Pistachio Processing Industry Wastewaters in a Batch-operated Aerobic Bioreactor
}

\section{Sevtap Tırınk}

Iğdır University: Iğdır Üniversitesi

Alper Nuhoğlu

Ataturk University: Ataturk Universitesi

Sinan Kul ( $\nabla$ sinankul@atauni.edu.tr)

Bayburt University https://orcid.org/0000-0002-7824-756X

\section{Research Article}

Keywords: Aiba biokinetic equation, biological treatment, mathematical modeling, pistachio processing industry wastewater

Posted Date: May 25th, 2021

DOl: https://doi.org/10.21203/rs.3.rs-448821/v1

License: (c) (i) This work is licensed under a Creative Commons Attribution 4.0 International License. Read Full License 


\title{
Investigation of the Biological Treatability of Pistachio Processing Industry Wastewaters in a Batch-operated Aerobic Bioreactor
}

\author{
Sevtap Tırınk ${ }^{1}$ Alper Nuhoğlu², Sinan Kul ${ }^{3 *}$ \\ ${ }^{1}$ Iğdır University, Environmental Health Program, 76000 Iğdır, TURKEY \\ ${ }^{2}$ Atatürk University, Department of Environmental Engineering, 25240 Erzurum, TURKEY \\ ${ }^{3}$ Bayburt University, Department of Emergency Aid and Disaster Management, 69010 Bayburt, TURKEY \\ e-mail: sinankul@bayburt.edu.tr
}

\begin{abstract}
This study encompasses investigation of treatment of pistachio processing industry wastewaters in a batch reactor under aerobic conditions, calculation of kinetic parameters and comparison of different inhibition models. The mixed microorganism culture used in the study was adapted to pistachio processing industry wastewaters for nearly one month and then concentrations from $50-1000 \mathrm{mg} \mathrm{L}^{-1}$ of pistachio processing industry wastewaters were added to the medium and treatment was investigated in batch experiments. The Andrews, Han-Levenspiel, Luong and Aiba biokinetic equations were chosen for the correlations between the concentration of pistachio processing industry wastewaters and specific growth rates, and the kinetic parameters in these biokinetic equations were calculated. The $\mu_{\max }, K_{s}$ and $K_{i}$ parameters, included in the Aiba biokinetic equation providing best fit among the other equations, had values calculated as $0.25 \mathrm{~h}^{-1}, 19 \mathrm{mg} \mathrm{L}^{-1}$, and $516 \mathrm{mg} \mathrm{L}^{-1}$, respectively.
\end{abstract}

Key words Aiba biokinetic equation, biological treatment, mathematical modeling, pistachio processing industry wastewater

\section{Introduction}

A member of the Anacardiaceae family, the pistachio includes only 11 species with the most economic species known to be Pistacia vera L. (Alma et al. 2004). The pistachio was first cultivated by the Hittites settling in southeast Anatolia and spread to Rome in the $1^{\text {st }}$ century and then on to Spain and France. The transition of pistachio to America occurred in 1853-54 (Kashaninejad and Tabil 2011). The pistachio grows in suitable microclimates from the 30-45 parallels in both north and south hemispheres of the globe (FAO 2018). Globally, countries producing pistachio are generally located in the northern hemisphere, and among these countries, Iran, USA and Turkey have shared the top three places in terms of production amounts for many years (FAO 2018). Pistachio yields product in an economic sense in regions with hot and dry summers (mean $25^{\circ} \mathrm{C}$ ), but very cool winters (mean $7.2^{\circ} \mathrm{C}$ ) (Ayfer 1990, Bilim and Polat 2006). Known as the king of nuts, pistachio may be described as a concentrated energy pill due to richness in proteins, vitamins and other minerals and nutritional features (Woodroof 1967). Pistachio contains twice the protein and four times the phosphorus compared to beef, in addition to being very rich in terms of potassium, iron, vitamin A and vitamin B1 (Woodroof 1967).

Pistachio harvest occurs in the second half of August and beginning of September in warm regions like Gaziantep and Şanllurfa located in Turkey (Ayfer 1964, Onay and Jeffree 2000). Globally, the pistachio processing industry (PPI) is rapidly developing and Turkey is $3^{\text {rd }}$ place in pistachio production after Iran and the USA (FAO 2018). In Turkey, a wet system is used to process pistachio and nearly $6 \mathrm{~m}^{3}$ wastewater per ton is formed (Fil et al. 2014). This rate shows variability linked to the size of the operation. Pistachio processing industry wastewater (PPIW)

Corresponding authors.

e-mail address: sinankul@bayburt.edu.tr 
contains high organic matter with polluting properties like high chemical oxygen demand (COD), high total organic carbon (TOC) and high total phenol (Fil et al. 2014).

There are 6 separate stages followed in order to strip the pistachio of the outer red covering. These stages are soaking, flaking, washing and shelling, empty-full separation, drying and cracking processes, in order, and the processes in these stages are shown in Fig 1 (Tirınk et al. 2020).

As seen in Fig 1, investigations of the PPI show that mean $100 \mathrm{~m}^{3}$ day $^{-1}$ water is used during flaking and shelling. It is known that nearly $20 \mathrm{~m}^{3}$ wastewater may form after processing 1 ton of pistachio while this rate may vary linked to the size of the operation (Doğru 2010).

PPIW contains dense suspended solid matter and phenols in the structure, in addition to high organic matter with polluting properties. Treatment is very difficult due to the toxic pollutants and discharge of PPIW into the receiving environment without treatment causes serious environmental problems. Due to these environmental problems, many studies related to treatment of PPIW were completed in countries where production occurs, especially; however, there are limited numbers of studies. Among studies about recycling and treatment of PPIW, a study investigated the effect of domestic wastewater treatment using the active sludge process on PPIW (Khademi et al. 2018), in addition to studies listing chemical and biological alternatives like coagulation/flocculation (Tırınk et al. 2020), Fenton (Demir and Rastgeldi 2018; Bayar et al. 2018), electrocoagulation (Fil et al. 2012; Güçlü 2014; Bayar et al. 2014; Y1lmaz and Köksal 2017; Isik et al. 2020), electrooxidation (Fil et al. 2012; Fil et al. 2014; Isik et al. 2020), and anaerobic treatment (Gür 2016; Ozay 2018; Gür and Demirer 2019). As a result of the high chemical oxygen demand of PPIW, there are no studies encountered in the literature about aerobic treatment.

As there are limited numbers of studies about treatment of PPIW, studies performed about similar wastewater will be a guide. Studies to be performed about this topic will contribute to the global literature while offering technological and economic choices for treatment of PPIW. This study investigated the biological treatment under aerobic conditions of wastewater due to production and processing of pistachio cultivated in Gaziantep located in southeast Turkey. Additionally, kinetic parameter values were calculated using data obtained from experiments with mixed cultures under aerobic conditions.

\section{Materials and Methods}

\section{Wastewater and chemical matters}

The PPIW used in the study was obtained from pistachio processing factories located in Gaziantep province in two different periods and the wastewater characterization is shown in Table 1 (Tirınk et al. 2020). All chemical agents required for the study were obtained commercially (Merck and Sigma quality).

\section{Experimental system}

The study used a reactor with $500 \mathrm{~mL}$ volume for batch experiments and the experimental system is shown in Fig 2. The mixing rate, medium temperature and $\mathrm{pH}$ values were chosen as $150 \mathrm{rpm}, 25 \pm 1^{\circ} \mathrm{C}$, and $7.5 \pm 0.5$, respectively. The reactor was continuously ventilated during batch experiments with dissolved oxygen (DO) values kept above $2 \mathrm{mg} \mathrm{L}^{-1}$. 


\section{Source of culture and culture media}

The microorganisms used for removal in an aerobic medium for PPIW were obtained from active sludge from the precipitation pool of Erzincan Urban Wastewater Treatment Plant and from a continuously-fed milk industry wastewater feed tank. Later microorganisms were fed with PPIW as carbon source and attempts were made to ensure adaptation of microorganisms to the wastewater. To sustain the viability of microorganisms, a fluid culture medium with content given in Table 2 was used (Kul and Nuhoğlu 2020; Ucun et al. 2010).

\section{Analytic techniques}

During the study, total phenol (TP) concentration was determined with the Folin-Ciocalteau method (Folin and Ciocalteu 1927; Atanassova et al. 2005) with suspended solid matter (SSM) and microorganism concentrations (X) determined spectrophotometrically at $525 \mathrm{~nm}$ wavelength (Nuhoğlu and Yalçın 2005; Kul and Nuhoğlu 2020). Additionally, for confirmation, gravimetric microorganism concentrations were tested with the standard methods (APHA 1995). Nitrate and nitrite concentrations were measured with a Dionex ICS 3000 brand ion chromatography device, while total organic carbon (TOC) and total nitrogen (TN) measurements were made with a Teldyne-Tekmar Apollo 9000 analysis device. Phosphate analysis used ammonium vanadomolybdate with absorbance measured with a spectrophotometer at $400 \mathrm{~nm}$ wavelength. The $\mathrm{pH}$ and temperature in the reactor were measured and recorded continuously with a WTW brand multiline P4 model multiparameter measurement device according to the electrometric method. The DO amount was determined by dipping an oximeter probe into the sample according to the membrane electrode method. Other analyses were performed as shown in standard methods (APHA 1995).

\section{Biological treatment and microbial kinetics}

The performance of biological processes used for wastewater treatment is linked to the dynamics of the substrate used and microbial growth. Thus, effective design and operation of systems requires an understanding of the basic principles of biological reactions and microorganism proliferation. Kinetic models are used with the aim of defining the removal of nutritional material from wastewater within the framework of some basic assumptions. Most biological treatment processes are very complex, operate within mutual interactions and contain mixed microbiological populations. For this reason, mathematical modelling of wastewater treatment systems is important to a very high degree. Microbial growth kinetics explain the substrate oxidation in a biological reactor and the production of biomass forming the total suspended solid concentration. The simplest and most-commonly used model for wastewater treatment is Monod kinetics, which is shown in Eq 1 (Winkler 1981; Schugerl 1991; Tchobanoglous et al. 2003).

$\mu=\frac{\mu_{\max } * S}{K_{S}+S}$

Here, $\mu$ is the specific reproduction rate $\left(h^{-1}\right), S$ is the substrate concentration (COD concentration in PPIW $\left(\mathrm{mg} \mathrm{L}^{-1}\right)$, and $\mathrm{K}_{\mathrm{s}}$ is the semi-saturated constant $\left(\mathrm{mg} \mathrm{L}^{-1}\right)$.

The $K_{\mathrm{s}}$ and $\mu_{\max }$ values given in Eq 1 vary according to the microorganisms used and the substrate type limiting growth in the medium. The Monod equation is mainly used to define reactions occurring at low rates with very high cell concentrations. In situations where the 
reaction occurs more rapidly, deviations develop in the Monod characteristic curve and it is inadequate to define the reaction kinetics. Different mathematical models like Andrews (Andrews 1968), Luong (Luong 1987), Han-Levenspiel (Han and Levenspiel 1988) and Aiba (Aiba et al. 1968) are successful in defining the effect of substrate inhibition on bacterial activity rates and these equations are shown in order in Eqs 2-5. These equations are related to the specific growth rate, in addition to specific substrate consumption rates.

$$
\text { Andrews } \quad \mu=\frac{\mu_{\max } * \mathrm{~S}}{\left(\mathrm{~K}_{\mathrm{S}}+\mathrm{S}\right)+\left(1+\frac{\mathrm{S}}{\mathrm{K}_{\mathrm{i}}}\right)}
$$

Luong

$$
\mu=\frac{\mu_{\max } * S}{K_{S}+S} *\left[1-\frac{S}{S_{m}}\right]^{n}
$$

$$
\text { Han-Levenspiel } \quad \mu=\mu_{\max }\left[1-\frac{s}{s_{m}}\right]^{n} * \frac{s}{s+K_{s}-\left[1-\frac{s}{S_{m}}\right]^{m}}
$$

$$
\text { Aiba } \quad \mu=\frac{\mu_{\max } * S}{K_{S}+S} * \exp \left(-\frac{S}{K_{i}}\right)
$$

Here, $\mathrm{K}_{\mathrm{i}}$ is the inhibition constant $\left(\mathrm{mg} \mathrm{L}^{-1}\right)$ and $\mathrm{S}_{\mathrm{m}}$ is the maximum substrate concentration that fully inhibits proliferation.

\section{Calculation of kinetic parameter values}

After microorganisms were habituated to PPIW in the aerobic medium for nearly one month, batch experiments began. For batch experiments, the microorganism concentration (X, mg L ${ }^{-1}$ ) was fixed, while different concentrations of PPIW ( $\mathrm{S}, \mathrm{mg} \mathrm{L}^{-1}$ ) were added to Erlenmeyer flasks and the variation in concentrations of $\mathrm{X}, \mathrm{S}$ and TP were monitored over time.

To calculate the specific reproduction rate $(\mu)$ in this study, Eq 6 was used. The logarithm of the concentration of $X$ varying over time in each experiment was obtained and the values were plotted on a graph against time and the $\mu$ values were calculated from the linear section of the slope.

$\ln X_{t}=\ln X_{0}+\mu * t$

Here, $X_{t}$ is the microorganism concentration at time $t\left(\mathrm{mg} \mathrm{L}^{-1}\right)$ and $\mathrm{X}_{0}$ is the initial microorganism concentration $\left(\mathrm{mg} \mathrm{L}^{-1}\right)$.

The initial concentrations of PPIW (S) and specific growth rates $(\mu)$ underwent non-linear regression considering the mathematical equations in Eqs 2-5. Using the obtained values, the biokinetic parameters in the Andrew, Luong, Han-Levenspiel and Aiba equations were calculated using the non-linear calculation module in Statistica 7.0 software.

\section{Mathematical model}

To model the variation occurring in $S$ and $X$ values in the batch reactor, the two-component Aiba-based biokinetic model was chosen. The mathematical expressions used to calculate $S$ and $\mathrm{X}$ values are given in Eqs 7-8. 
$\frac{d X}{d t}=r_{2}$

Using Equation 7 and Equation 8, the reaction rates were organized as given in Eqs 9-10.

$r_{1}=-\frac{\mu_{\max } * S * X}{\left(K_{S}+S\right) * Y} * \exp \left(-\frac{S}{K_{i}}\right)$

$r_{2}=\frac{\mu_{\max } * S * X}{\left(K_{S}+S\right)} * \exp \left(-\frac{S}{K_{i}}\right)-b * X$

Here, $\mathrm{Y}$ is the yield factor and $\mathrm{b}$ is the death constant $\left(\mathrm{h}^{-1}\right)$.

The yield factor for substrate concentrations (dry biomass weight/substrate weight) was calculated using Eq 11.

$\mathrm{Y}=\frac{\Delta X}{\Delta S}$

\section{Results and Discussion}

\section{Removal from PPIW under aerobic conditions}

For nearly one month, microorganisms used for removal from PPIW were habituated to PPIW under aerobic conditions. Later, initial microorganism concentrations were kept fixed and substrate with amounts varying from 50 to $1000 \mathrm{mg} \mathrm{L}^{-1}$ were added and batch experiments began. During the study, mixing rate was $150 \mathrm{rpm}, \mathrm{pH}$ value was $7.5 \pm 0.5$ and temperature was set to $25 \pm 1{ }^{\circ} \mathrm{C}$. The variation over time for different initial X, S and TP concentrations in the study is shown in Fig 3.

Fig 3 shows the easily degraded organic portion of PPIW was consumed by microorganisms over time. As the initial concentration $S$ increased in the study, the adaptation time for microorganisms lengthened and in parallel with this, the removal durations of the $S$ concentrations increased.

\section{Removal kinetics for PPIW in batch reactor under aerobic conditions}

One of the most important points that requires care when revealing the proliferation kinetics of microorganisms is choosing the equation showing the correlation between $\mu$ and $\mathrm{S}$. Data obtained from the graphs in Fig 3 and with the aid of Eq 6 calculated the $\mu$ value by taking the variation in the $X$ value over time. For each $S_{0}$ value, the $\mu$ values obtained in the exponential breeding phase and coefficients using Eqs 2-5 were obtained and shown in Table 3, along with the graphs in Fig 4.

All these models mathematically express the inhibition effect of enzymes and substrates on proliferation of microorganisms. When deciding on the type of inhibition when attempting enzyme inhibition, the first step is determination of the inhibition type with graphic methods. Rapid development of computer technology in recent years has ensured linearization of enzyme 
inhibition kinetics and determination with non-linear regression solution techniques without requiring graphic methods. The non-linear regression solution techniques provide fit of experimental data to many inhibition models and selection of the most appropriate model is linked to a variety of assessment criteria. Statistical parameters are one of these assessment criteria. In the literature, there are many studies related to proliferation of microorganisms in the presence of inhibitors. In these studies, many parameters like $\mu_{\max }, \mathrm{K}_{\mathrm{s}}$ and $\mathrm{K}_{\mathrm{i}}$ can be determined with graphic methods or with non-linear regression solution techniques (Antunes et al. 2003).

252

253

Assessment of results obtained after kinetic analyses used the boundary conditions included in Table 4 (Luong 1987). Among models abiding by the boundary conditions, the kinetic coefficients for the model with smallest $\sum\left(\mu-\mu_{i}\right)^{2}$ total were taken and the model with best fit to experimental results was identified using Table 3 . Here, $\mu_{\mathrm{e}}{ }^{*}$ is the largest $\mu$ value measured during experiments.

The biokinetic parameters $\left(\mu_{\max }, K_{s}, K_{i}, S_{m}, n\right.$ and $m$ ) calculated with the Andrew, Luong, HanLevenspiel and Aiba models in studies with similar wastewater and in this study are comparatively presented in Table 5 .

As can be seen in Table 5, pure and mixed cultures were used to obtain the kinetic profile in biodegradation processes. The $\mu_{\max }$ value calculated in this study was identified as $0.2517 \mathrm{~h}^{-1}$ according to the Aiba biokinetic model with best fit. Additionally, the $\mathrm{K}_{\mathrm{s}}$ value in this study was $19.9013 \mathrm{mg} \mathrm{L}^{-1}$ which is relatively smaller than values calculated in other studies, which may be explained by the high affinity of the mixed culture for PPIW. The $\mathrm{K}_{\mathrm{i}}$ value was 516.434 $\mathrm{mg} \mathrm{L}^{-1}$ which shows that PPIW may have inhibitory effects at relatively higher concentrations. The literature shows that differences observed between biokinetic coefficients may be linked to many factors like environmental factors, differences in dominant microbial species and degree of adaptation of microbial cultures to wastewater.

\section{Investigation of fit with Aiba model}

Eqs 9-10 were solved at the same time to calculate the model for variations in $\mathrm{S}$ and $\mathrm{X}$ values within the reactor over time. Eqs 9-10 used the Aiba model coefficients. The model accepting $\mathrm{Y}=0.32 \mathrm{~g} \mathrm{~g}^{-1}$ and $\mathrm{b}=0.001 \mathrm{~h}^{-1}$ was applied to initial concentrations from 50-1000 $\mathrm{mg} \mathrm{L}^{-1}$. Results obtained at the end of experiments may be seen in Fig 5.

Fig 5 shows the values obtained for experiments with different $\mathrm{S}_{0}$ concentrations with $\mathrm{S}$ and $\mathrm{X}$ values in the reactor found with simultaneous solution of a 2-component simple model range. The real-time increase in $S$ and $X$ values found higher values than in the model. Profiles obtained using the same model coefficients for $\mathrm{S}$ and $\mathrm{X}$ showed deviations from these values. To improve these deviations, the Berkeley Madonna program curve-fit feature was used and the program was operated again with $b=0.0005-0.008 \mathrm{~h}^{-1}$ and $Y=0.2-1 \mathrm{~g} \mathrm{~g}^{-1}$. The mean of the different $Y$ and $b$ values found for wastewater concentrations between $50-1000 \mathrm{mg} \mathrm{L}^{-1}$ were 0.3 $\mathrm{g} \mathrm{g}^{-1}$ and $0.0005 \mathrm{~h}^{-1}$, respectively. The results obtained with these new optimum $\mathrm{Y}$ and $\mathrm{b}$ values can be seen on Fig 6 .

Due to the complicated compounds in PPIW, none of the trialed models were successful in reflecting the measured substrate variation profiles. All of the trialed models predicted that the 
substrates would be degraded in shorter durations. Contrary to this, as can be seen on graphs obtained using this data, the model appears to be successful in showing the $\mathrm{X}$ variation.

Of the three biokinetic constants included in the Aiba biokinetic equation, $\mathrm{K}_{\mathrm{i}}$ measures the inhibition intensity caused by the inhibitory material, $K_{\mathrm{s}}$ is the semi-saturated constant and $\mu_{\max }$ value explains half of the measured $\mathrm{S}$ concentration. The $\mathrm{K}_{\mathrm{s}}$ value also shows the affinity of the microorganism for the substrate. Additionally, if there is a substrate inhibitor, it is not possible to observe the real $\mu_{\max }$ value. Thus, $\mathrm{K}_{\mathrm{s}}$ gains an assumptive meaning. In this situation, if $\mathrm{d} \mu / \mathrm{dS}=0$, the $S$ value reaches maximum value $\left(\mathrm{S}^{*}\right)$ and the $\mu$ value $(\mu *)$ at this concentration must be calculated as given in Eqs 13-14 (Nuhoğlu and Yalçın 2005, Kul and Nuhoğlu 2020).

$S^{*}=\sqrt{K_{S} K_{i}}$

$\mu^{*}=\frac{\mu_{\max }}{2\left(\sqrt{\left.\frac{K_{s}}{K_{i}}\right)+1}\right.}$

The inhibition value given in Eq 14 reflects not just the $\mathrm{K}_{\mathrm{i}}$ value but also the $\mathrm{K}_{\mathrm{s}} / \mathrm{K}_{\mathrm{i}}$ ratio. Large $\mathrm{K}_{\mathrm{s}} / \mathrm{K}_{\mathrm{i}}$ and small $\mu^{*}$ values are associated with $\mu_{\max }$, and this is the largest inhibition degree (Nuhoğlu and Yalçın 2005). Using the kinetic constant values calculated for $\mu_{\max }, K_{\mathrm{s}}$ and $\mathrm{K}_{\mathrm{i}}$ with the aid of Eqs 13-14, the $\mathrm{S}^{*}$ and $\mu^{*}$ values were calculated as $101.379 \mathrm{mg} \mathrm{L}^{-1}$ and 0.1827 $\mathrm{h}^{-1}$, respectively (Nuhoğlu and Yalçın 2005, Kul and Nuhoğlu, 2020). The graphs obtained with the aid of these calculated values are shown in Fig 7.

When Fig 7 is investigated, all the trialed models predicted the substrate would be degraded in shorter durations. Contrary to this, as can be seen from graphs obtained using data for the model, more successful graphs were obtained when the $S^{*}$ and $\mu^{*}$ values were used to show $\mathrm{S}$ and $\mathrm{X}$ variations.

\section{Conclusion}

In this study attempting to treat the significant pollutant of PPIW in a batch reactor under aerobic conditions, the following results were obtained.

The study used a mixed microorganism culture obtained from Erzincan urban active sludge facility and adapted to PPIW for nearly 1 month and investigated the treatment of PPIW with different amounts from $50-1000 \mathrm{mg} \mathrm{L}^{-1}$ in batch experiments. Due to the biologically easily degraded organic matter content, at the end of 12 hours removal efficiency was $83 \%$ for $50 \mathrm{mg} \mathrm{L}^{-1}$ substrate concentration, $85 \%$ for $100 \mathrm{mg} \mathrm{L}^{-1}$ substrate concentration, $87 \%$ for $250 \mathrm{mg} \mathrm{L}^{-1}$ substrate concentration, $88 \%$ for $500 \mathrm{mg} \mathrm{L}^{-1}$ substrate concentration, $87 \%$ for $750 \mathrm{mg} \mathrm{L}^{-1}$ substrate concentration and $84 \%$ for $1000 \mathrm{mg} \mathrm{L}^{-1}$ substrate concentration.

The Andrews, Han-Levenspiel, Luong and Aiba biokinetic equations were chosen for the association between initial PPIW concentration and specific growth rate and the kinetic parameters in these equations were calculated. Considering the regression coefficients $\left(\mathrm{R}^{2}\right)$ and $\sum\left(\mu-\mu_{\mathrm{i}}\right)^{2}$ values for the curves drawn using the model equations and kinetic parameter values, the biokinetic equation with best fit among the equations was the Aiba. The values for the $\mu_{\max }, K_{\mathrm{s}}$ and $\mathrm{K}_{\mathrm{i}}$ parameters included in this equation were calculated as $0.25 \mathrm{~h}^{-1}, 19$ $\mathrm{mg} \mathrm{L}^{-1}$, and $516 \mathrm{mg} \mathrm{L}^{-1}$, respectively.

Large $\mathrm{K}_{\mathrm{s}} / \mathrm{K}_{\mathrm{i}}$ and small $\mu^{*}$ values are associated with $\mu_{\max }$ and this is the largest inhibition degree. 
Using the kinetic constant values calculated for $\mu_{\max }, K_{s}$ and $K_{i}$, the $S^{*}$ and $\mu^{*}$ values were calculated as $101.379 \mathrm{mg} \mathrm{L}^{-1}$ and $0.1827 \mathrm{~h}^{-1}$. It appeared that the simulation operated with these values was much more efficient.

\section{Ethics approval and consent to participate}

This article does not contain any studies with human participants or animals performed by any of the authors.

\section{Consent for publication}

Not applicable.

\section{Availability of data and materials}

The datasets used and/or analysed during the current study are available from the corresponding author on reasonable request.

\section{Competing interests}

Sevtap Tırınk declares that she has no conflict of interest. Alper Nuhoğlu declares that he has no conflict of interest. Sinan Kul declares that he has no conflict of interest.

\section{Funding}

Not applicable.

\section{Authors' contributions}

ST and AN conceived and designed research. ST conducted experiments. ST and SK analyzed data. SK wrote the manuscript. All authors read and approved the manuscript.

\section{Acknowledgements}

The authors are grateful for laboratory support from Atatürk University Department of Environmental Engineering.

\section{References}

Agarwal R, Mahanty B, Venkata Dasu V (2009) Modeling growth of Cellulomonas cellulans NRRL B 4567 under substrate inhibition during cellulase production. Chem Biochem Eng Q 23(2): 213-218.

Aiba S, Shoda M, Nagatani M (1968) Kinetics of product inhibition in alcohol fermentation. Biotechnol Bioeng 10(6): 845-864. doi: 10.1002/bit.260100610

Alma MH, Nitz S, Kollmannsberger H, Diğrak M, Efe FT, Yılmaz N (2004) Chemical composition and antimicrobial activity of the essential oils from the gum of Turkish pistachio (Pistacia vera L.). J Agr Food Chem 52(12): 3911-3914. doi: 10.1021/jf040014e

Andrews JF (1968) A mathematical model for the continuous culture of microorganisms utilizing inhibitory substrates. Biotechnol Bioeng 10(6): 707-723. doi: 10.1002/bit.260100602

Antunes F, Marinho HS, Barreto MC, Pavao ML, Pinto RE (2003) Diagnosis of enzyme inhibition based on the degree of inhibition. BBA-Gen Subjects 1624(1-3): 11-20. doi: 10.1016/j.bbagen.2003.08.007

APHA (1995) Standard methods for the examination of water and wastewater. American Public Health Association, Washington DC, USA 
Atanassova D, Kefalas P, Petrakis C, Mantzavinos D, Kalogerakis N, Psillakis E (2005) Sonochemical reduction of the antioxidant activity of olive mill wastewater. Environ Int 31(2): 281-287. doi: 10.1016/j.envint.2004.10.004

Ayfer M (1964) Pistachio nut culture and its problems with special reference to Turkey. Univ Ank Fac Agr Yearbook 189-217.

Ayfer M (1990) Antepfıstığının dünü bugünü geleceği. Türkiye 1: 11-12.

Bayar S, Boncukcuoğlu R, Yılmaz AE, Fil BA (2014) Pre-treatment of pistachio processing industry wastewaters (PPIW) by electrocoagulation using Al plate electrode. Separation Sci Tech 49(7): 1008-1018. doi: 10.1080/01496395.2013.878847

Bayar S, Massara TM, Boncukcuoglu R, Komesli OT, Malamis S, Katsou E (2018) Advanced treatment of industrial wastewater from pistachio processing by Fenton process. Desalin Water Treat 112: 106-111. doi: 10.5004/dwt.2018.22197

Bilim HI, Polat R (2006) Antepfıstığı çıtlama makinası tasarımı. Tarım Makinaları Bilimi Dergisi 2(3): 203-209.

Demir Ö, Rastgeldi B (2018) Treatment of the pistachio processing wastewater using Fenton's, ultrasound with Fenton's, and coagulation processes. Environ Prot Eng 44(1). doi: 10.5277/epe180113

Dey S, Mukherjee S (2010) Performance and kinetic evaluation of phenol biodegradation by mixed microbial culture in a batch reactor. Int J Water Res Environ Eng 3(2): 40-49.

Doğru S (2013) The pre-treatment of pistachio industry wastewater and the investigation of biological tretability of them in to the aerobic conditions. Master Thesis, Atatürk University

FAO (2018) Production quantities of pistachios by country the United Nations: Food and Agriculture Organization of the United Nations. http://www.fao.org/faostat/en/\#data/QC/visualize. Accessed 18 March 2021

Fil BA, Boncukçuoğlu R, Yılmaz AE, Bayar S (2012). Pre-Treatment Studies of Pistachio Processing Wastewaters by Electro-Oxidation Methods. Iğdır Univ J Inst Sci Tech 2(2), 2936.

Fil BA, Boncukcuoğlu R, Y1lmaz AE, Bayar S (2014) Electro-oxidation of pistachio processing industry wastewater using graphite anode. Clean-Soil Air Water 42(9): 1232-1238. doi: $10.1002 /$ clen.201300560

Folin O, Ciocalteu V (1927) On tyrosine and tryptophane determinations in proteins. J Biol Chem 73(2): 627-650.

Güçlü D (2014) Optimization of electrocoagulation of pistachio processing wastewaters using the response surface methodology. Desalin Water Treat 1-10. doi: $10.1080 / 19443994.2014 .907752$

Gür E (2016) Anaerobic treatability and biogas production potential of pistachio processing wastewater with upflow anaerobic sludge blanket (UASB) reactor. Master Thesis, Middle East Technical University

Gür E, Demirer GN (2019) Anaerobic digestability and biogas production capacity of pistachio processing wastewater in UASB reactors. J Environ Eng 145(8): 04019042. doi: 10.1061/(ASCE)EE.1943-7870.0001559

Han K, Levenspiel O (1988) Extended Monod kinetics for substrate, product, and cell inhibition. Biotechnol Bioeng 32(4): 430-447. doi: 10.1002/bit.260320404

Isik Z, Arikan EB, Ozay Y, Bouras HD, Dizge N (2020) Electrocoagulation and electrooxidation pre-treatment effect on fungal treatment of pistachio processing wastewater. Chemosphere 244: 125383. doi: 10.1016/j.chemosphere.2019.125383

Kashaninejad M, Tabil LG (2011) Pistachio (Pistacia vera L.). In: Elhadi MY (ed) Postharvest biology and technology of tropical and subtropical fruits, 4th edn. Woodhead Publishing, Cambridge 
Khademi F, Yaghmaeian K, Taheri M, Hayatabadi MA, Nasiri A, Malakootian M (2018) Effects of pistachio processing wastewater on treatment efficiency of urban wastewater using activated sludge process. Environ Health Eng And Manage J 5(3): 167-174.

Kul S, Nuhoğlu A (2020) Removal kinetics of olive-mill wastewater in a batch-operated aerobic bioreactor. J Environ Eng 146(3): 04019122. doi: 10.1061/(ASCE)EE.1943-7870.0001654

Luong J (1987) Generalization of Monod kinetics for analysis of growth data with substrate inhibition. Biotechnol Bioeng 29(2): 242-248. doi: 10.1002/bit.260290215

Nuhoğlu A, Yalçın B (2005) Modelling of phenol removal in a batch reactor. Process Biochem 40(3-4): 1233-1239. doi: 10.1016/j.procbio.2004.04.003

Onay A, Jeffree CE (2000) Somatic embryogenesis in pistachio (Pistacia vera L.). In: Jain SM, Gupta PK, Newton RJ (eds) Somatic embryogenesis in woody plants, Vol 6. Springer, Switzerland

Ozay Y, Ünşar EK, Işı1k Z, Yılmaz F, Dizge N, Perendeci NA, Mazmancı MA, Yalvac M (2018) Optimization of electrocoagulation process and combination of anaerobic digestion for the treatment of pistachio processing wastewater. J Clean Product 196: 42-50. doi: 10.1016/j.jclepro.2018.05.242

Saravanan P, Pakshirajan K, Saha P (2011) Kinetics of phenol degradation and growth of predominant Pseudomonas species in a simple batch stirred tank reactor. Bulg Chem Commun 43(4): 502-509.

Schugerl K (1991) Bioreaction Engineering, Characteristic Features of Bioreactors, Vol. 2. John Wiley\&Sons, UK

Tchobanoglous G, Burton FL, Stensel HD (2003) Metcalf\&Eddy wastewater engineering: treatment, disposal, reuse, International edn. McGrawHill, New York

Tırınk S, Nuhoğlu A, Kul S (2020) Characterization of pistachio processing industry wastewater and investigation of chemical pretreatment. Environ Research and Techno 3(4), 209-216. doi: 10.35208/ert.800721

Ucun H, Yıldız E, Nuhoğlu A (2010) Phenol biodegradation in a batch jet loop bioreactor (JLB): kinetics study and pH variation. Bioresource Technol 101(9): 2965-2971. doi: 10.1016/j.biortech.2009.12.005

Winkler MA (1981) Biological treatment of waste-water, Ellis Horwood

Woodroof JG (1967) Tree nuts: production, processing, products. Avi Pub, USA

Yilmaz AE (2017) The investigation of parameters affecting on treatment of pistachio processing industry waste water by continuous electrocoagulation process. Iğdır Univ J Inst Sci Tech 7(1): 95-103. 
Figures

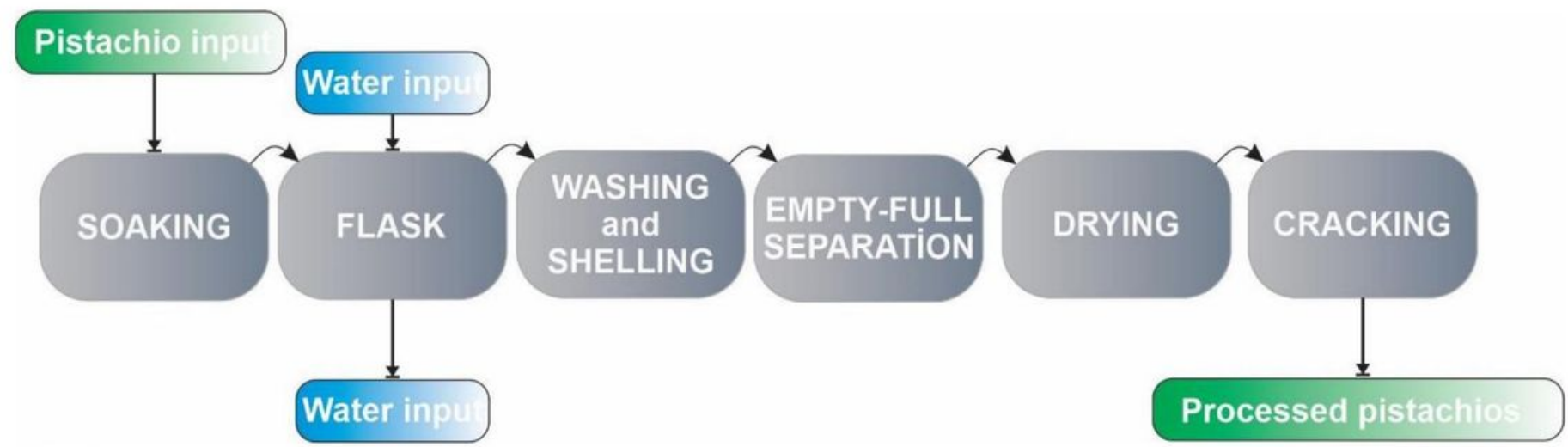

Fig 1.

Figure 1

Production process in the PPIW 


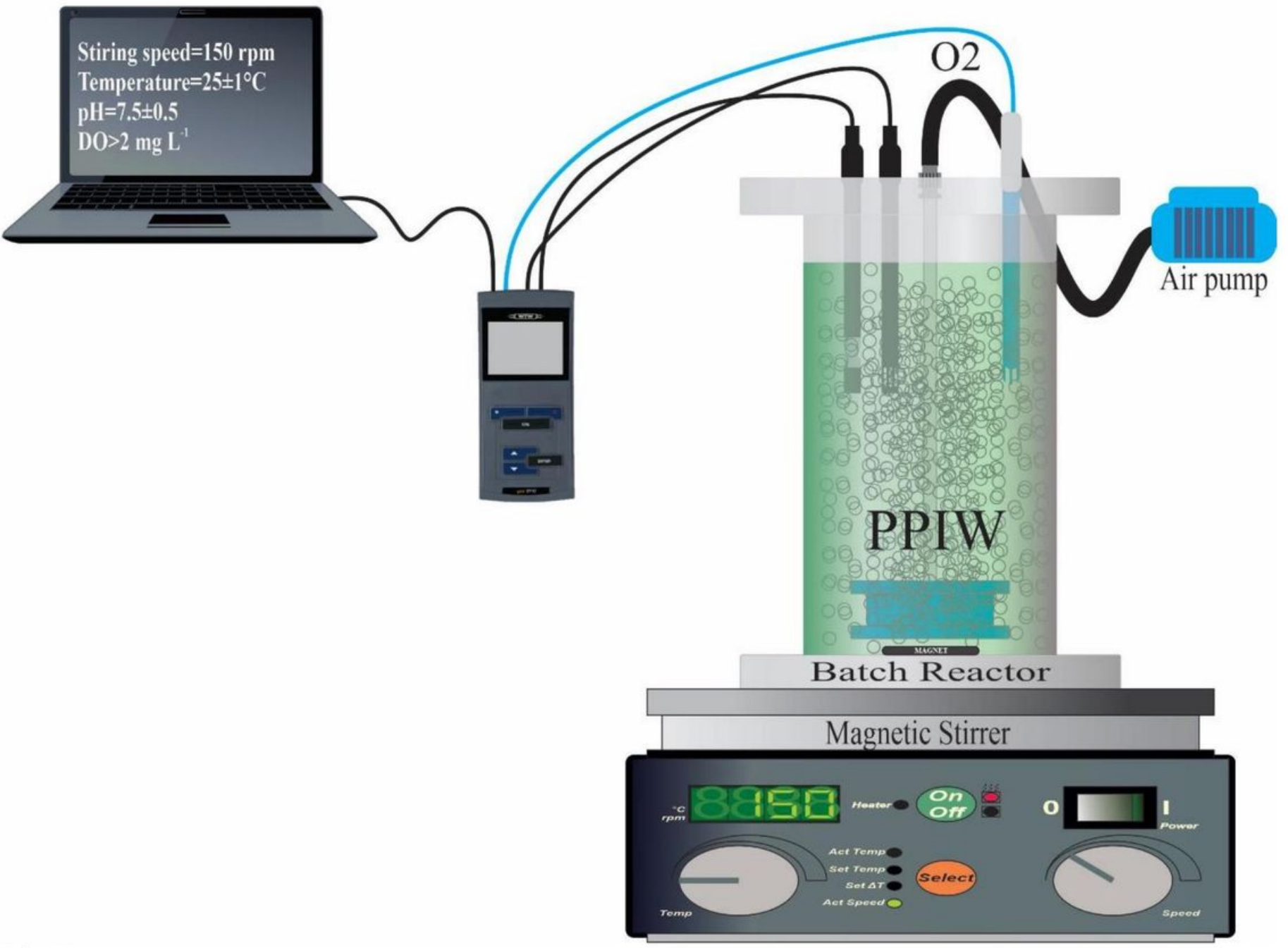

Fig 2.

Figure 2

Experimental setup used during batch experiments 

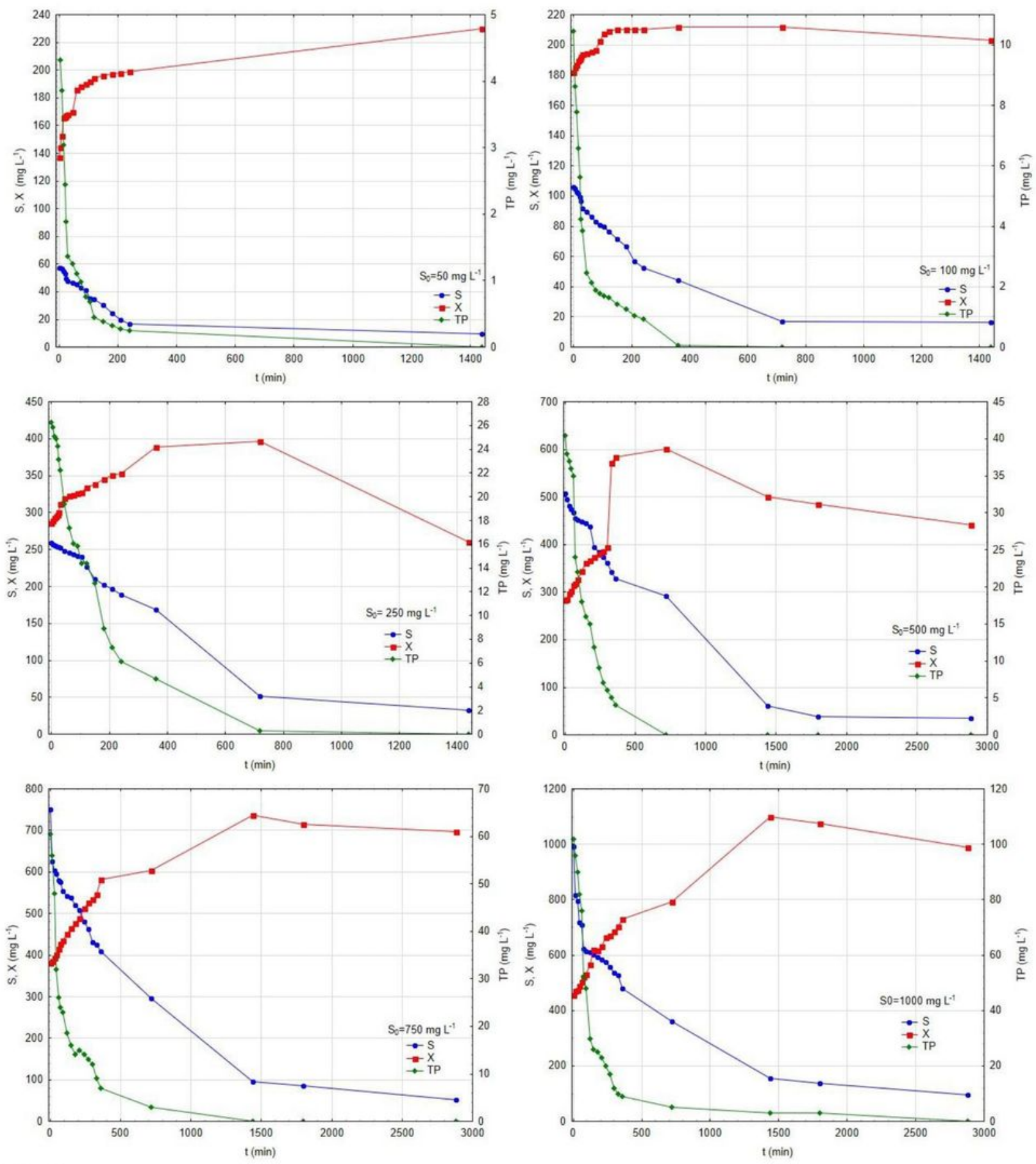

Fig 3.

\section{Figure 3}

Variation in X, S and TP concentrations for PPIW with different initial concentrations 

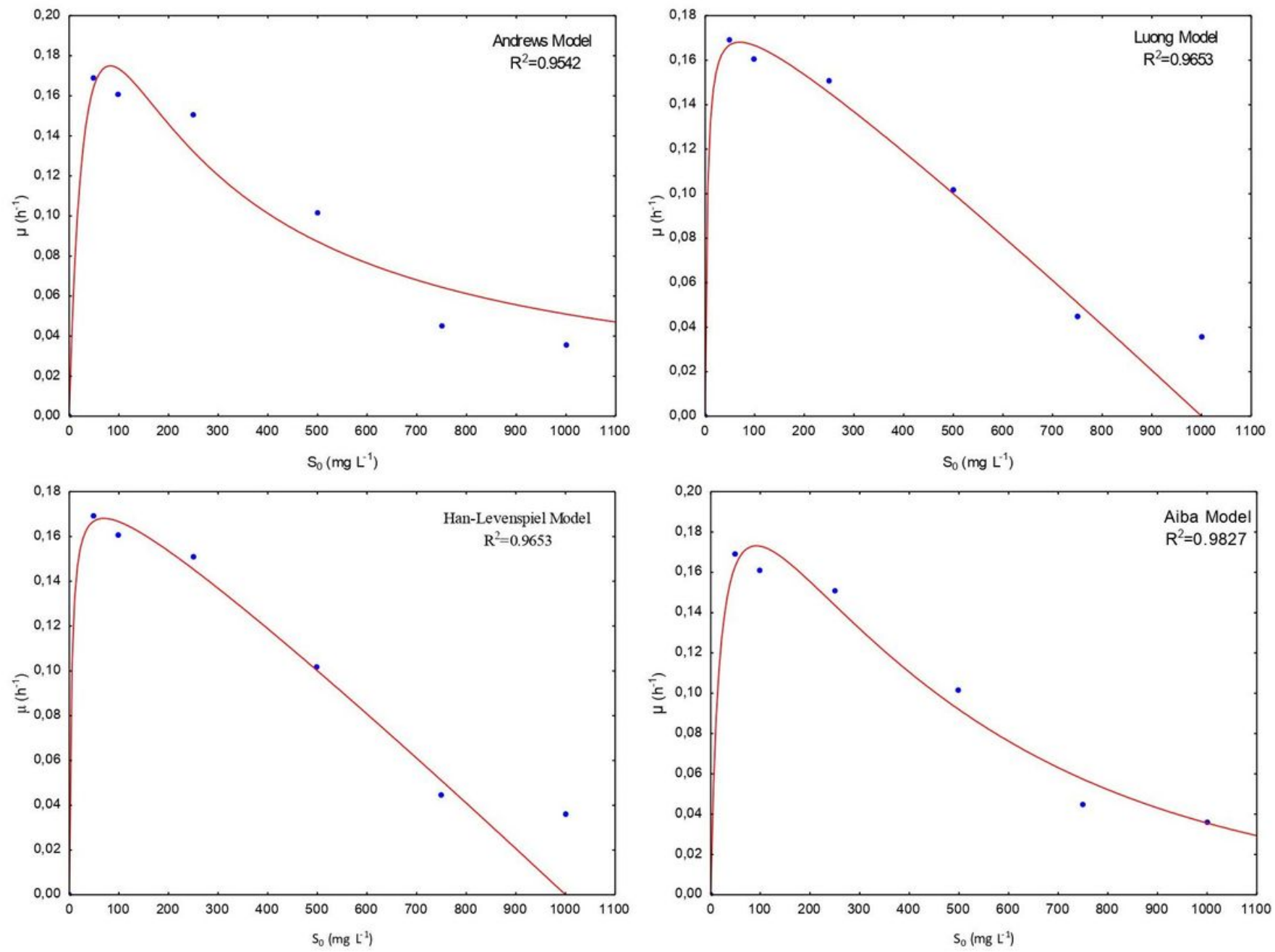

Fig 4.

Figure 4

Fit of data obtained from PPIW with biological substrate inhibition models 

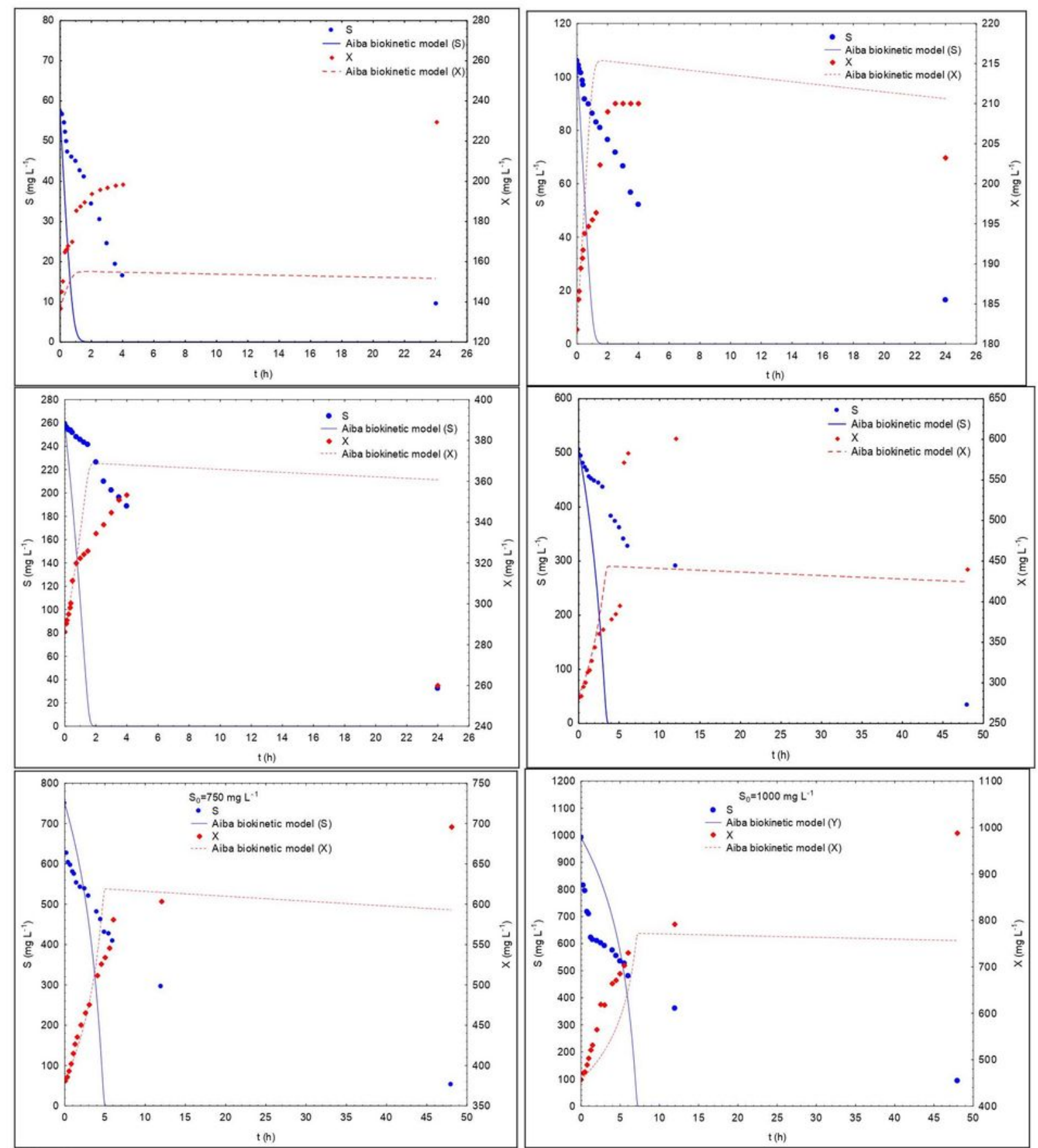

Fig 5.

Figure 5

Fit of Aiba biokinetic model to data obtained 

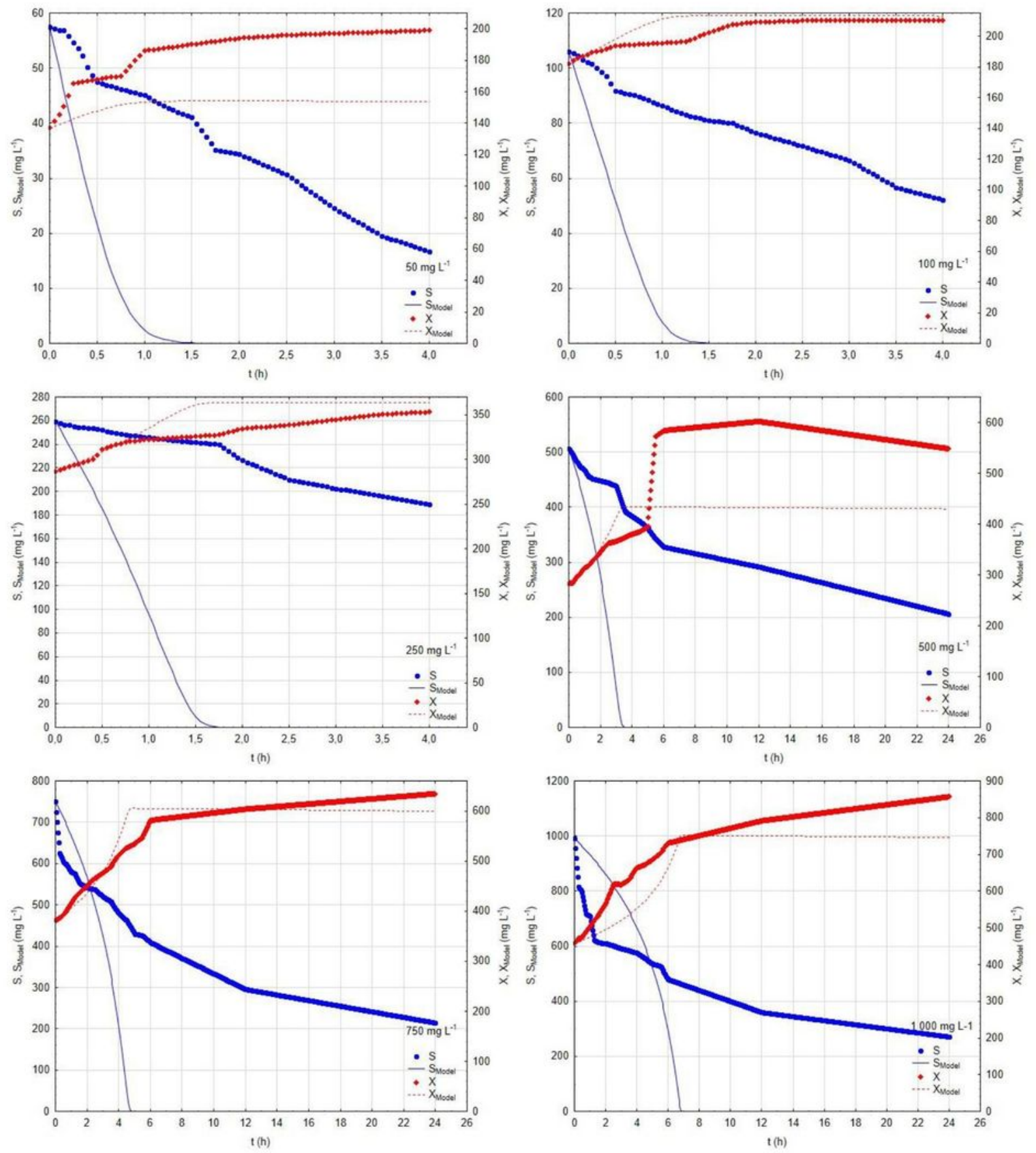

Fig 6.

\section{Figure 6}

Fit of Aiba biokinetic model with obtained data for optimum $Y$ and $b$ values 

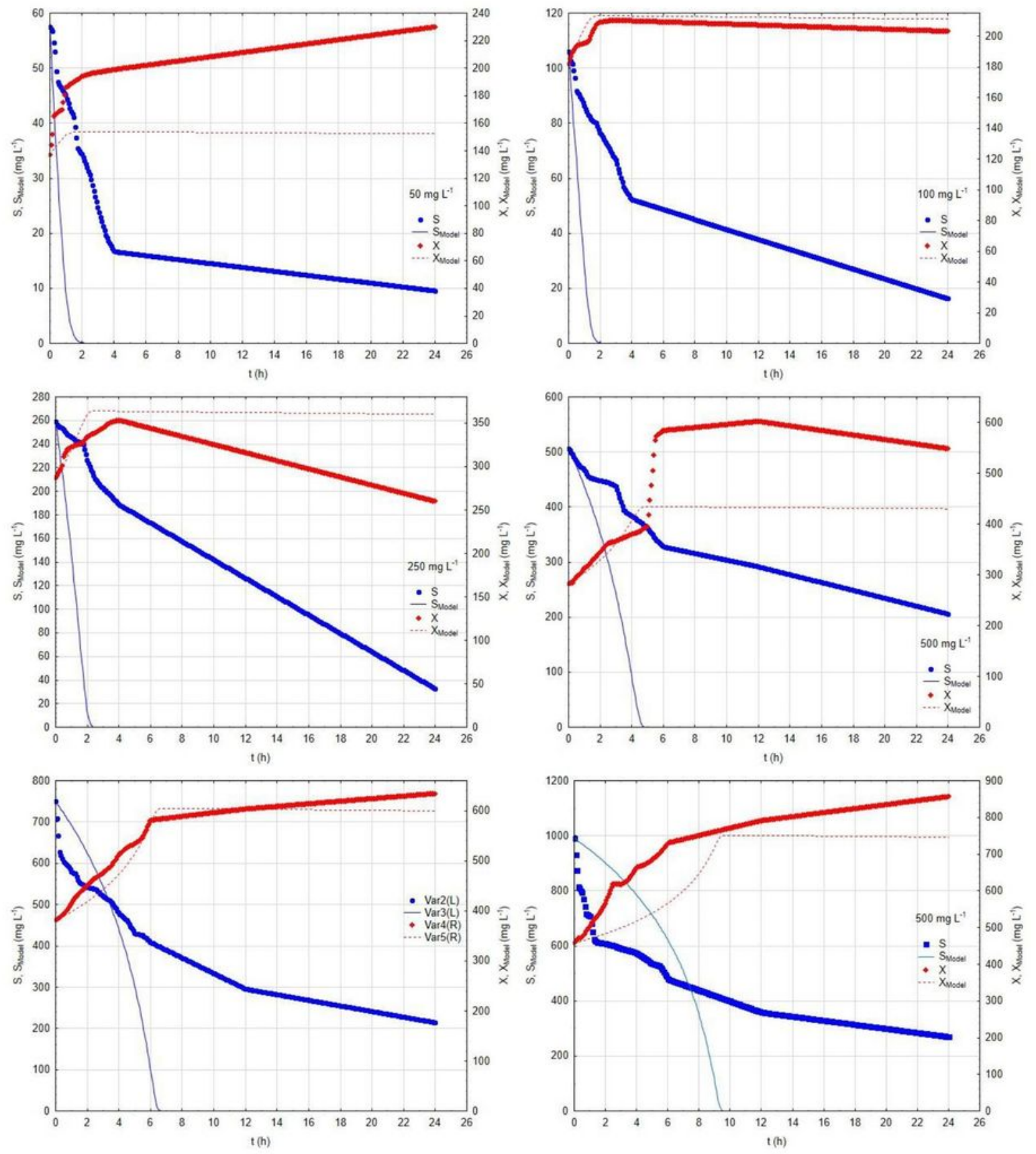

Fig 7.

\section{Figure 7}

Fit of Aiba biokinetic model with data for data obtained using $S^{*}$ and $\mu^{\star}$ 